\title{
The epistemology of particulars: Human geography, case studies and 'context'
}

DOI:

10.1016/j.geoforum.2005.08.001

Link to publication record in Manchester Research Explorer

\section{Citation for published version (APA):}

Castree, N. (2005). The epistemology of particulars: Human geography, case studies and 'context'. Geoforum, 36(5), 541-544. https://doi.org/10.1016/j.geoforum.2005.08.001

\section{Published in:}

Geoforum

\section{Citing this paper}

Please note that where the full-text provided on Manchester Research Explorer is the Author Accepted Manuscript or Proof version this may differ from the final Published version. If citing, it is advised that you check and use the publisher's definitive version.

\section{General rights}

Copyright and moral rights for the publications made accessible in the Research Explorer are retained by the authors and/or other copyright owners and it is a condition of accessing publications that users recognise and abide by the legal requirements associated with these rights.

\section{Takedown policy}

If you believe that this document breaches copyright please refer to the University of Manchester's Takedown Procedures [http://man.ac.uk/04Y6Bo] or contact uml.scholarlycommunications@manchester.ac.uk providing relevant details, so we can investigate your claim.

\section{OPEN ACCESS}


 \\ The epistemology of particulars: Human geography, case studies and 'context'}

Since the mid-1980s, so-called 'case study' research has become ever more prominent in the journal articles and monographs produced by human geographers. A case study usually involves investigating one or more phenomena in some depth in one place, region or country. What makes it an actual or potential 'case' is that the phenomena under investigation (e.g. workfare policies, flexible manufacturing technologies, postmodern architecture) can be found in other places, regions or countries: the case may thus be unique but is not singular. In certain fields of human geography, particular cases have been the focus of so much research they've become iconic (think of Manchester, my own city, as well as Los Angeles and Vancouver). Focussing on these and other cases has become a means of negotiating two opposing views of the world that have a pedigree in the discipline. One the one side, a nomothetic perspective presumes an ontological regularity in both pattern and process between otherwise different contexts. On the other side, an idiographic worldview accents the contingent and enduring differences that make 'context' no mere 'modifier' of ostensibly general processes. Starting over twenty years ago, critical realism convinced many human geographers that this either/or choice could be avoided; the 'both/and' slash of Marxian dialectics had a similar effect on some in the discipline. As a result, it has these days become disciplinary common sense that geographical difference 'matters' but not in a stereotypically Hartshornian way. That is, geographical difference is seen to matter not just for its own sake but also because it has constitutive effects on processes, rules and regulations that are 'stretched' over wide spans of space and time. Case study research in human geography thus

\footnotetext{
${ }^{1}$ In this sense, those who see themselves doing case study research differ in sensibility from an older generation of area specialists. The latter, to hazard a generalisation, tended to write about a specific place, region or country for its own sake: as of interest in its own right rather (unless comparative research was being undertaken).
}

serves an important function. It shows the world to be persistently diverse (notwithstanding the 'flat earth' hubris of some analysts of globalisation). Yet it shows that this diversity arises out of multiscaled relations such that it does not emerge sui generis.

For some time I have had a sneaking suspicion that, notwithstanding its other virtues, an awful lot of case Many geographical researchers seem to favour case study research while, paradoxically, not really understanding its nature and rationale. I want to illustrate this seeming paradox with reference to recent published work on neoliberalism and the non-human world (some of it published in this journal). I 'pick' on this work (if that's the word) simply because I have spent a lot of my time, in recent months, reading it with a view to understanding what wider lessons we can learn about nature's neoliberalisation. In other words, this work is not especially guilty of the problems I will identify below. In highlighting these problems I want to raise a series of questions, the answers to which may produce some future clarity about the why and wherefore of the case approach in human geography as a whole.

In the last couple of years, a growing body of theoretically informed empirical research has appeared on the subject of nature's neoliberalisation. Critical geographers like Karen Bakker, Jessica Budds, Jeffrey Bury, Nik Heynen, Roger Keil, Becky Mansfield, James McCarthy, Tom Perreault, Scott Prudham, Paul Robbins, Morgan Robertson and Kevin St. Martin (hereafter Bakker et al.) have greatly advanced our understanding of what neoliberal policies do to the biophysical world (and vice versa). ${ }^{2}$ Their highly grounded research focuses on specific aspects of the natural environment (e.g. water resources, wetlands, trees, fish and

\footnotetext{
${ }^{2}$ I use the term 'critical geography' in a broad sense to designate research that in some way takes issue with the prevailing social and/or environmental order.
} study research by human geographers is ill-conceived. 
minerals) and their governance in particular parts of the world (e.g. Milwaukie in Heynen's case (2005); England and Wales in Bakker's (2003) case; Bolivia in Perreault's (2005) case; the North Pacific ocean in Mansfield's (2004a) case). This research reveals the path-dependency, contingency and varied outcomes of specific kinds of neoliberal policies in specific situations.

For Bakker et al. this research emphasis on geographical difference is clearly seen as a good thing. Becky Mansfield (2004a, p. 566), for instance, sees the key contribution of her work as "avoid[ing] treating neoliberalism as an unchanging force that is applied in different contexts". She argues that it is "geographically constituted" (Mansfield, 2004a) and illustrates this empirically with reference to Alaska pollock (see also Mansfield, 2004b). Likewise, Bakker (forthcoming, p. 4) sees post-1989 water privatisation in England and Wales as a "specific variant" of neoliberalism and bases this claim on the fact that water has not been truly commodified (whereas commodification applies in other cases of nature's neoliberalisation). Finally, to offer a third example, Prudham's (2004, p. 357) study of deregulated water testing in Ontario concludes that "each specific neoliberalisation is just that, specific, contingent and geographically constituted".

What are we to make of these claims? The new empirical literature on nature's neoliberalisation appears to be meeting a need that Wendy Larner and others identified a few short years ago. Larner (2003, p. 21), concerned that critical geographers avoid treating neoliberalism as a hegemonic monolith, asked them to identify "different variants of neoliberalism ... [and] the hybrid nature of contemporary policies and programmes ...". Likewise, introducing a set of essays on neoliberalism and the city, Brenner and Theodore (2002) argued that 'actually existing neoliberalism' is a plurality not a thing: that is, a set of spatio-temporally specific neoliberalisations. Taking these arguments to heart, the research of Bakker et al. achieves three useful things. First, general theoretical claims about 'neoliberalism' in the singular are subject to the complications and rigours of empirical analysis. Second, in geographical terms, neoliberal ideas and policies are shown to be variegated rather than serially produced across space. Finally, in normative terms the substantive and empirical diversity revealed creates space for tailored criticism and finessed evaluations. In sum, new case research on nature's neoliberalisation appears to be avoiding the errors of previous attempts in human geography to apply 'transition models': that is, supposedly widespread and relatively uniform systemic changes that are (wrongly) seen to mark-off a new 'era' from its predecessor.

However, these virtues will ultimately count for little unless some deeper problems in the research literature are addressed. These problems can be identified by way of a brief analysis of comments made by Mansfield and Prudham in their above mentioned works-comments that are hardly exclusive to these two authors. Mansfield (2004a, p. 580) concludes one her recent essays thus: "The particular forms that neoliberalism takes should not be taken as aberrant from an ideal, or as not really neoliberal". Likewise, Prudham (2004, p. 357) ends his Ontario study with the observation that "we need to appreciate both diversity and consistency across particular neoliberalisations". In one sense, the comments of both authors are as sensible as they are uncontentious. Mansfield and Prudham are arguing that in order to know what is different about particular neoliberalisations of nature we need to know what they have in common. As Jamie Peck (2004, p. 396) notes in another context, "splitting differences between varieties of neoliberalism cannot be an end in itself, not least because it begs questions about the common roots and shared features of the unevenly neoliberalised landscape that confronts us all'. However, unless we have a clear understanding of how 'common roots and shared features' can be identified, we run two risks. The first is the risk of identifying purely formal (rather than substantive) similarities between different neoliberalisations. The second and related risk is of classifying otherwise different cases as neoliberal when, in fact, the differences outweigh meaningful commonalities. Let me explain.

Case studies scrutinise one or more phenomena 'in context'. In other words, while these phenomena may be very large in their scale of operation or exist independently in numerous places, they are examined conjuncturally: their 'local' articulation with other things may alter their operation across space and time. Context is one of those polysemic terms that means multiple things in geographical discourse. For some it is a synonym for all things empirical or 'concrete' (Marx's famous 'unity of the diverse'). For others context is a synonym for the scale of everyday life: that is, place or the local scale. However, as Cox and Mair (1989) insightfully argued many years ago, both conceptions of context are only partially valid. In the first place, one can theorise about context insofar as there may be processes specific to a context that can be isolated conceptually. ${ }^{3}$ Secondly, Cox and Mair also pointed out that context is necessarily multi-scalar. The local is not the only scale at which multiple enduring and contingent phenomena come together empirically. For instance, the global is as much a 'context' as the many 'locals' that comprise it; it is not some homogenous scale overlaying all that exists 'below' it.

The relevance of all this to the research of Bakker et al. is as follows: it is currently unclear which of the meanings of context are in play in individual studies

\footnotetext{
${ }^{3}$ And this is what is normally meant when the term 'meso-level theory' is used in academic literature.
} 
182 and is thus unclear in what specific sense the published 183 case studies are 'cases'. It is one thing to recognise that 184 'neoliberalism' as such does not exist (except in the 185 books and papers of Milton Friedman, Friedrich Hayek 186 and Richard Epstein). But it is quite another to show 187 how different cases are, in Barnett's $(2005$, p. 8) words, 188 "varieties of a single genus". To do this one needs to ad189 dress a raft of vexing questions. Firstly, one cannot 190 know the genus in isolation from its particular forms 191 of expression. In other words, one must undertake 192 extensive empirical research in the first instance to be 193 able to identify whether the commonalities between 194 cases are sufficiently strong to warrant seeing them as 195 variations on a theme. One does not start with a text196 book definition of neoliberalism and then look for exam197 ples of it 'on the ground'. So-called 'neoliberalism' is, as 198 Mansfield (2004a) rightly argues, a diverse set of prac199 tices. Thus far, the research of Bakker et al. has not been 200 comparative in significant measure. It thus falls to read201 ers of their work to make good on Prudham's injunc202 tion. This is challenging work because it obliges us to 203 determine the criteria whereby apparently (and really) 204 different cases of nature's neoliberalisation can, in a 205 meaningful sense, be deemed similar. These criteria are 206 far from being self-evident.

207 I mentioned above the risk of identifying merely for208 mal similarities among cases. It is a prevalent risk be209 cause it's far easier to draw formal comparisons than 210 substantive ones. For instance, by abstracting from the 211 complexity of any number of case studies, one could eas212 ily generate the following list of 'commonalities-among213 differences':
- Privatisation (i.e. the assignment of clear private property rights to social or environmental phenomena that were previously state owned, unowned or communally owned).

- Marketisation (i.e. the assignment of prices to phenomena that were previously shielded from market exchange or for various reasons unpriced). ${ }^{4}$

- Deregulation (i.e. the 'roll back' of state 'interference' in numerous areas of social and environmental life).

- Reregulation (i.e. the deployment of state policies to facilitate privatisation and marketisation of everwider spheres of social and environmental life).

- Market proxies in the residual public sector (i.e. the state-led attempt to run remaining public services along private sector lines).

- The construction of flanking mechanisms in civil society (i.e. the state-led encouragement of civil society groups [charities, NGOs etc.] to provide services that interventionist states did or could provide for citi-

\footnotetext{
${ }^{4}$ This is what critics usually call 'commodification' which, in one definition of the term, means the assignment of an exchange value to an object or idea.
}

zens; these civil society groups are also seen as being 233 able to offer compensatory mechanisms that can 234 tackle any problems citizens suffer as a result of the 235 previous five things listed).

This six-point list is clearly so abstract that it fails to tell us how and with what effects otherwise different neoliberalisations work. It constitutes nothing more than an ideal-type in Jessop's (2002, p. 460) sense of the term. Substantive comparisons between cases must be processual not categorical. Even Peck and Tickell's (2002) helpful dichotomies of 'hard'/'soft', 'shallow'/'deep' and 'roll back/roll out' neoliberalism are too descriptive to get us far in understanding geographically differentiated causality. Yet the difficulty is that analysts must abstract processes from their contexts in order to identify commonalities between cases - and in so doing they may mimic the 'unrealistic' act of formal comparison in the guise of substantive comparison.

This leads to a second set of issues in comparing cases of nature's neoliberalisation. How does one know one is dealing with a distinct type of neoliberal practice as opposed to the contingently variable operation of neoliberal practices that are far more widespread than the case in question? For instance, I mentioned above that Bakker takes commodification as a key criteria for distinguishing water's neoliberalisation from other biophysical phenomena. Mansfield, meanwhile, makes much of the open-access nature of ocean fisheries in her analyses of market-led pollock harvesting. Are these differences ones of degree or kind when compared with each other? And by what criteria do we answer this question? Going back many years the critical realist language of necessity and contingency emboldened many critical geographers to think these sorts of questions can be answered clearly. But I am not sure so sure. If one looks at the research by Bakker et al. it seems to me that 'different' neoliberalisations of nature are being identified in multiple ways both theoretically and empirically. It is very hard to parse this literature in a way that avoids the banality and formalism of the six-point list above (believe me I've tried).

One 'solution' to these difficulties is to focus on geographical scale. Neoliberal policies operative at the international and national scales may seem to resolve the problem of identifying commonalities among erstwhile different cases. For instance, McCarthy's (2004) study of how certain firms in the US uphold their 'right' to pollute the environment is situated within the international context of the NAFTA. Since NAFTA applies to the US, Canada and Mexico, other researchers could undertake studies similar to McCarthy's elsewhere in North America. They could draw direct comparisons because they would be looking at the same 'framework conditions' for the local or regional actions of corporations re. the natural environment. However, reasonable 
289 as this scenario may seem it is actually implausible. The 290 reason is that even international policies (neoliberal or 291 otherwise) do not operate uniformly across the territo292 ries to which they apply. Even if only for contingent rea293 sons, these policies can be amended, ignored, 294 unenforced or only partially adhered to at the national 295 or sub-national scales.

296 Let me summarise. The new geographical literature 297 on nature's neoliberalisation provides us with a wealth 298 of insights that take us beyond the fiction of a homoge299 nous 'neoliberalism' acting upon an undifferentiated bio300 physical world. However, these insights, I have argued, 301 are specific to the cases and context researched by Bak302 ker et al. Because key questions about how 'difference' is 303 defined are not answered consistently or (in some cases) 304 explicitly in the research literature, it is unclear what 305 comparisons between cases are about, or how they 306 might be achieved in practice. Just because 'neoliberal307 ism' features as a keyword in the diverse studies of 308 Bakker et al. does not mean these studies are about 309 the same thing in degree or kind. If 'case studies' of 310 nature's neoliberalisation are to avoid the 'trap' or 311 'dead-end' of idiography then much more work needs 312 to be done. Greater clarity in defining objects of analysis 313 is required both theoretically and empirically; questions 314 about levels and scales of abstraction need to be 315 addressed in a sophisticated way; and, finally, the "trans316 lation-rules' for comparing apparently similar (or differ317 ent) cases need to be established. Only then, it seems me, 318 will we know what 'wider' lessons to draw from the 319 growing body of concrete research into nature's 320 neoliberalisation.

321 Though I have no clever solutions to the problems 322 identified in this commentary, I do have one general rec323 ommendation. I think we need more rather than less 324 attention to philosophical-cum-theoretical questions as 325 a way of improving the quality and comparability of 326 empirical case research. In many parts of human geogra327 phy, I suspect that doing case research ('getting one's 328 hands dirty') is valued more highly than the hard work 329 of figuring out how best to do case research. This latter 330 work has a vital philosophical and theoretical dimension 331 because it involves issues of ontology, epistemology, 332 concept-formation, classification and so on. It is the 333 kind of work apparent in recent debates about geo334 graphical scale (involving Neil Brenner, Erik Swynge335 douw, Sallie Marston and Neil Smith, among others), 336 which have been highly abstract yet conducted with ref337 erence to a plethora of existing case studies. I think more 338 of this concretised abstract discussion (not an oxymo- ron) is what's required if the problems I've identified here are to be effectively addressed.

\section{Acknowledgement}

I wish to thank Andrew Leyshon, Nik Heynen and Alan Rudy for constructive criticisms of this commentary.

\section{References}

Bakker, K., forthcoming. Neoliberalizing nature? Market environmentalism in water supply in England and Wales. Annals of the Association of American Geographers.

Barnett, C., 2005. The consolations of neoliberalism. Geoforum 36 (1), 7-12.

Brenner, N., Theodore, N., 2002. Cities and the geographies of 'actually existing neoliberalism'. Antipode 34 (3), 349-379.

Cox, K., Mair, A., 1989. Levels of abstraction in locality studies. Antipode 21 (2), 212-232.

Heynen, N., Robbins, P., 2005. The neoliberalization of nature: governance, privatization, enclosure and valuation. Capitalism, Nature, Socialism 16 (1), 1-4.

Jessop, B., 2002. Liberalism, neoliberalism and urban governance. Antipode 34 (3), 452-472.

Larner, W., 2003. Neoliberalism? Society and Space 21 (4), 509-512.

Mansfield, B., 2004a. Rules of privatization: contradictions in neoliberal regulation of North Pacific fisheries. Annals of the Association of American Geographers 94 (3), 565-584.

Mansfield, B., 2004b. Neoliberalism in the oceans: "rationalization", property rights and the commons question. Geoforum 35 (3), 313326.

McCarthy, J., 2004. Privatizing conditions of production: trade agreements as neoliberal environmental governance. Geoforum 35 (3), 327-342.

Peck, J., Tickell, A., 2002. Neoliberalizing space. Antipode 34 (3), 380 404.

Perreault, T., 2005. State restructuring and the scale politics of rural water governance in Bolivia. Environment and Planning A 37 (2), 263-284.

Prudham, S., 2004. Poisoning the well: neoliberalism and the contamination of municipal water in Walkerton, Ontario. Geoforum 35 (3), 343-360.

346

347

348

349

350

351

352

353

354

355

356

357

358

359

360

361

362

363

364

365

366

367

368

369

370

371

372

373

374

375

376

377

\section{N. Castree \\ University of Manchester \\ School of Geography \\ Oxford Road \\ Manchester M13 9PL \\ United Kingdom}

E-mail address: noel.castree@manchester.ac.uk 